The strength of the tar can be increased up to the following tar-paste, which is often very well tolerated with good results :-

\begin{tabular}{|c|c|c|c|c|}
\hline $\begin{array}{l}\text { Crude coal tar } \\
\text { Zinc oxide } \quad \cdots\end{array}$ & $\begin{array}{l}\cdots \\
\cdots\end{array}$ & $\cdots$ & $\cdots$ & $\begin{array}{ll}\text { pts. } & 2 \\
\text { pts. } & 2\end{array}$ \\
\hline $\begin{array}{l}\text { Corn starch } \ldots \\
\text { Petrolatum ... } \\
\quad \text { Mix and com }\end{array}$ & $\begin{array}{c}\ldots \\
\ldots \\
\text { ooth. }\end{array}$ & $\begin{array}{l}\cdots \\
\cdots\end{array}$ & $\begin{array}{l}\ldots \\
\cdots\end{array}$ & $\begin{array}{l}\text { pts. I6 } \\
\text { pts. I6 }\end{array}$ \\
\hline
\end{tabular}

This should be cleaned off with olive oil.

Treatment should be continued on these lines until the horny layer is normal and the fissures have quite healed.

A word may be said about the blepharitis. It often persists after the remainder has cleared up. It is a danger area, as it provides a focus for a general relapse. The lids should be bathed every two hours and the crusts removed. A weak mercurial such as ung. hyd. ox. flav. should be applied thickly.

Some authorities have advocated epilation of the scalp in the catarrhal stage. There is no doubt that the period of the treatment is greatly curtailed in many cases if this is done. It can be carried out by X-rays or thallium acetate (if the child is under the age of 7 years).

Treatment on general lines is important and will include abundant good food, vitamin A, and exposure to the ultra-violet lamp. Streptococcal vaccines are of use given intradermally, the dosage being adjusted so that reactions are not excessive, the first dose being 2 mils. Protein shock therapy, using sterile milk intramuscularly, has appeared to benefit some very chronic cases.

The after-care of these children is extremely important. Their health should be maintained at a high level and care should be taken that they are kept out of doors when possible. After an attack they should have a period of convalescence for at least six months. Regular inspection of the skin should be maintained for at least two years. Fissures about the nose and the ears are very liable to recur and should be promptly and carefully treated.

The importance of this is because relapses can occur up to adult life and many cases of sycosis follow a chronic blepharitis and a streptococcal rhinitis. Recurrent erysipelas of the face with permanent blocking of the lymphatics and chronic oedema is liable to occur when fissures return in the nose.

\title{
COMMENTS ON A CASE OF RENAL FAILURE.
}

\author{
BY A. E. CLARK-KENNEDY, M.D., F.R.C.P., \\ Assistant Physician, London Hospital, Ec.
}

THIS patient, a man aged $5^{2}$ and a labourer, was well until eight months ago, when he began to complain of thirst, nocturnal frequency and polyuria. Six months ago he woke up one morning to find that he had partially lost the sight of his left eye, and it was at about this time that he began to complain of rather frequent and severe attacks of headache. His sight recovered gradually, but about one month ago there was a similar occurrence, and he says the vision of the left eye, though improving, is still impaired. Recently he has had several attacks of vomiting without any pain, and his friends have 
commented on his increasing pallor. He himself will tell you that he has never at any time had any swelling of his face, hands or feet.

Such briefly is his history. When you come to examine him you will notice that he is obviously anæmio-at a guess his hæmoglobin must be in the neighbourhood of 50 per cent. His tongue is dry and furred. The apex beat is forcible and at least an inch outside the nipple line. There are no murmurs, but the hypertrophy of the lett heart is easily explained; if you take his blood-pressure you will find it in the region of 220 systolic and 130 diastolic. There are no abnormal physical signs in the lungs, abdomen or central nervous system. When you look at the fundi you will see small hæmorrhages in both retinæ and a number of patches of white exudate; one very noticeable one near the macular region in the left eye is responsible for the visual defect. The specific gravity of his urine is 1008 , and has been round about that figure to my knowledge for the last two weeks. On boiling it yields a moderately dense cloud of albumin. Lastly, I want you to note particularly that there is no oedema of the feet.

You say the diagnosis is obvious-chronic nephritis. What kind of chronic nephritis? Chronic interstitial nephritis says the more old-fashioned of you. Azotæmic nephritis says the biochemist. Arteriosclerotic kidney says another. Nephritis repens suggests someone else. Malignant sclerosis of $\mathrm{Fahr}$ says the up-to-date student of German medical literature. But I think it would be wiser not to commit yourselves on a diagnosis of nephritis too quickly.

All you are really justified in saying at the moment is that this patient is suffering from renal failure. For you must learn to distinguish between renal disease and renalo failure, just as you habitually make the distinction between heart disease and hearto failure. In many cases of chronic nephritis there is renal disease, as evidenced by hæmaturia, albuminuria and œdema. Edema in chronic nephritis is probably not so much due to failure of the kidney to excrete water, as to toxic damage of the capillaries causing leakage into the tissue spaces, or to depletion of the plasma of protein with lowering of the osmotic pressure of the blood to the point at which fluid accumulates in the tissues. When kidney failure does supervene polyuria comes on, and œdema, if previously present, disappears. For in kidney failure it is not so much a question of the kidney failing to excrete water as of the kidney failing to concentrate urea in the urine up to the usual percentage figure. The kidney then excretes a large volume of urine containing a lower percentage of urea, and thus for a time, on account of this polyuria, the excretion of the daily quotum of urea is maintained, while the patient will complain of thirst, polyuria and frequency. At this stage the specific gravity of the urine, which depends for all practical purposes on the percentage of urea which it contains, is fixed at a low figure, as here, and for some reason at present unknown the blood-pressure rises and the heart and vessels hypertrophy. Sooner or later, however, in spite of the polyuria, the urea in the blood rises from the normal $0.04 \mathrm{grm}$. up to $0^{\circ} 3 \mathrm{grm}$. or more, and it is at this stage that albuminuric retinitis supervenes. In this patient the blood-urea now stands at $0^{\circ} 15 \mathrm{grm}$. per cent., and some of you have seen the albuminuric retinitis for yourselves.

This, then, is the clinical picture of renal failure : thirst, polyuria and dehydration of the body; headache, nausea and vomiting; rise of blood-pressure, cardio-vascular hypertrophy and albuminuric retinitis. There is also anæmia and fixation of the specific gravity of the urine at a low figure, and later uræmia. I emphasize again the 
usual absence of œdema. If œdema does supervene in these cases, it is usually cardiac, not renal, due to heart failure, secondary to the rise of blood-pressure.

Now what pathological processes will give rise to this condition of renal failure ? The answer is almost any pathological process which may affect both kidneys. Thus occasionally it may be produced by bilateral renal calculi or bilateral renal tuberculosis. Congenital cystic disease of the kidneys is a not uncommon cause. Chronic prostatic obstruction with bilateral hydronephrosis will produce it, as also will neurological conditions associated with chronic retention of urine-I saw a case in a man with tabes only the other day. A few cases have been described lately in which great hypertrophy of the bladder has been found with bilateral hydronephrosis, but no organic obstruction of the urethra has been present. Such cases have been attributed to an achalasia or a failure of the bladder sphincter to relax-I saw a case of this kind which was admitted to hospital with uræmia not so very long ago. Then again, the changes which take place in the arteries of the kidney as the result of primary high blood-pressure starve the kidney of blood and leads to the so-called secondary ischæmic nephritis-this presents the same clinical picture. Then you have cases of this kind which may follow a true infective or toxic nephritis.

There are, however, some cases which present this clinical picture and in which no surgical cause can be found, in which primary hyperpiesis seems improbable, and in which there is no history of previous renal disease. Such cases, and this is an example, appear to be a primary fibrosis of the kidney, and have been described by Volhard and Fahr as malignant sclerosis. Lead sometimes appears to play a part in the æetiology of this condition, and if you ask the patient he will tell you that he worked in lead works for many years until he was advised to give it up on account of recurrent attacks of lead colic.

\section{A CASE FOR DIAGNOSIS.}

BY DR. W. BURTON-WOOD, M.D., M.R.C.P., Physician to Out-Patients, City of London Hospital, Diseases of Heart and Lungs.

FRED E., aged I5, waterworks assistant, enjoys good health, but has been kept under medical observation for two years on account of a pulmonary abnormality.

Previous

History.

At the age of 5 , when his mother was attending with the patient at right lung." a school inspection, she was told that he had "a black patch on the

At the age of 13 , when again undergoing medical inspection at school, the doctor detected an abnormal condition of the right lung and referred the case to hospital. There is no history of bronchial catarrh or pneumonia.

\section{Family History. Nil ad rem.}

At the age of 13 he attended the Victoria Park Chest Hospital. At

History of

Present

Condition. this time he looked well, but complained that at times he suffered from pain in the right side of the chest. This was never severe and did not interfere with school or play. Since this time he has enjoyed good health, but has been kept under observation. He was admitted to hospital about June, I930, for a short period for purposes of special investigation.

Present Condition.

The patient is a healthy looking lad and well nourished. The chest is well formed and symmetrical. There is a slight diminution of expansion 